\title{
Application of the Composite Hydrotalcite (Mg/Al)/Chitosan as Adsorbent for the Treatment of Raw Water of Municipal Waterworks PDAM Bandarmasih
}

\author{
Maulana Wahyu Noor Ramadhan ${ }^{1}$, Chairul $\operatorname{Irawan}^{1}$, Hesti Wijayanti ${ }^{1}$, Muthia Elma ${ }^{1}$ \\ ${ }^{1}$ Chemical Engineering Master Program, Lambung Mangkurat University, Jl. A. Yani KM. 36 \\ Banjarbaru 70714, Indonesia
}

\begin{abstract}
This research has been carried out about raw water treatment of Municipal Waterworks PDAM Bandarmasih using composite of hydrotalcite $(\mathrm{Mg} / \mathrm{Al})$ and chitosan (from of Haruan and Papuyu fish) by adsorption process of color $(\mathrm{PtCo})$, iron $(\mathrm{Fe})$, and turbidity values. This research intended to produce raw drinking water from the utilization of the composite hydrotalcite $(\mathrm{Mg} / \mathrm{Al}) /$ chitosan as adsorbent with variations doses of 1 , 2 and $3 \mathrm{~g} / \mathrm{L}$ within 24 hours, stirrer rate of $200 \mathrm{rpm}$ at room temperature. The results showed that the decrease in color value was $96.78 \%, 95.03 \%$, and $92.98 \%$. Percentage decrease in iron $(\mathrm{Fe})$ was $94.38 \%, 93.78$ and $91.87 \%$ and percentage of turbidity reduction were $97.98 \%, 79.76 \%$, and $76.56 \%$. Optimum condition in variations of hydrotalcite $(\mathrm{Mg} / \mathrm{Al}) /$ chitosan dose was $1 \mathrm{~g} / \mathrm{L}$ for a duration of 24 hours, $200 \mathrm{rpm}$ at room temperature, where at that condition resulted in a decrease in color, iron and turbidity become of $11 \mathrm{PtCo}$, $0.047 \mathrm{mg} / \mathrm{L}, 0.76 \mathrm{NTU}$. The results were appropriate in the drinking water requirements in accordance with the Regulation of the Minister of Health of the Republic of Indonesia No: 492/MENKES/PES/IV/2010.
\end{abstract}

Keywords: hydrotalcite $(\mathrm{Mg} / \mathrm{Al})$, chitosan, color, iron, turbidity, raw water

\section{INTRODUCTION}

The human population in South Kalimantan according to Badan Pusat Statistik in 2016 is around 4 million, while for Banjarbaru the community is almost 250 thousand, resulting in a problem, one of which is liquid waste. Adsorption is one effective way to eliminate a component that is not desired. Many researchers had been researched adsorption mainly with hydrotalcite because it has a large surface area and it has a synergistic effect between layers so that it attracts the interest of researchers.

Correspondence: Chairul Irawan, Chemical Engineering Master Program, Lambung Mangkurat University, Jl. A. Yani KM. 36

Banjarbaru 70714, Indonesia, E-mail:

cirawan@ulm.ac.id

Journal of Wetlands Environmental Management Vol 7, No 1 (2019), 76 - 83

http://dx.doi.org/10.20527/jwem.v7.v1.197
Heraldy et al. research (2012) found that the utilization of PLTU distillation waste for the manufacture of $\mathrm{Mg} / \mathrm{Al}$ hydrotalcite of methyl orange (MO) adsorption resulted in a MO adsorption rate of $7.30 \times 10^{-4}$ seconds. Imaniah (2016) has researched the comparison of $\mathrm{Mg} / \mathrm{Al}-\mathrm{NO}_{3} \quad$ hydrotalcite-magnetic composites (HT-M) and $\mathrm{Mg} / \mathrm{Al}-\mathrm{NO}_{3}$ hydrotalcite-magnetic calcination as adsorbent to eliminate remazol yellow dye, where the result was HT-M optimum adsorbed dyes as much as $7.67 \times 10^{-5} \mathrm{~mol} / \mathrm{gram}$ at $\mathrm{pH} 4$ with a reaction time of 90 minutes and HT-MKAL of dyestuffs which optimum adsorption was $7.74 \times 10^{-5} \mathrm{~mol} /$ gram at $\mathrm{pH} 3$ within 90 minutes.

The hydrotalcite $(\mathrm{Mg} / \mathrm{Al})+$ chitosan study which is chitosan obtained from local fish scales in the Banjarmasin wetland area. The chitosan is used as an adsorbent to deal with the PDAM Bandarmasih raw water problem in 
Banjarmasin. Its found that the parameters are not following drinking water according to the regulation standards of the Minister of Health of the Republic of Indonesia No 492/MENKES/PER/IV/2010. Resulted from the analysis of the PDAM office state that color (Pt-Co) 342, turbidity of 37.55 (NTU), and iron $(\mathrm{Fe})$ concentration in the raw water of $0.836 \mathrm{mg} / \mathrm{L}$, while the requirements for drinking water are $15 \mathrm{PtCo}, 5 \mathrm{NTU}$, and 0.3 $\mathrm{mg} / \mathrm{L}$, respectively. Therefore the parameters needed to be treated.

\section{MATERIALS AND METHODS}

\section{Materials and Methods}

Chitosan derived from original fish scales of Kalimantan called Haruan (Channa striata) and Papuyu (Anabas testudineus). The other materials used in this research are $40 \% \mathrm{NaOH}$, $\mathrm{HCl}(0.275-1 \mathrm{~N}), \mathrm{Al}\left(\mathrm{NO}_{3}\right)_{3} .9 \mathrm{H}_{2} \mathrm{O} 0.01 \mathrm{~N}$, $\mathrm{Mg}\left(\mathrm{NO}_{3}\right)_{2} .6 \mathrm{H}_{2} \mathrm{O} \quad 0.05 \mathrm{~N}, \mathrm{NaCO}_{3} \quad 0.1 \mathrm{M}$, distilled water, acetic acid glacial (Merck) 2\% (b/v), $\mathrm{NaHCO}_{3} 0.05 \mathrm{M}, \mathrm{NaOH} 0.1 \mathrm{M}, \mathrm{NaOH}$ (0.25-2.5N), concentrated $\mathrm{HCl}$ (Merck), chitosan, raw water of Municipal Waterworks PDAM Banjarmasin.

Chitosan will be extracted by (No and Meyers, 1995) method with some modifications. Chitosan synthesis involves three significant steps such as deproteinization (using $\mathrm{NaOH}$ ), demineralization (using $\mathrm{HCl}$ ) and deacetylation processes.

\section{Chitosan Preparation from Fish Scales}

Deproteinization

A solution of $\mathrm{NaOH}$ with a concentration

Journal of Wetlands Environmental Management

Vol 7, No 1 (2019), 76 - 83

http://dx.doi.org/10.20527/jwem.v7.v1.197 of $3.5 \%$ is mixed with fish scales and heated at a temperature of $65^{\circ} \mathrm{C}$. When heated, the mixture is stirred using a magnetic stirrer for 2 hours. The mixture is cooled at room temperature $\left(25^{\circ} \mathrm{C}\right)$, then filtered while washing using distilled water. The mixture is heated for 24 hours at $65^{\circ} \mathrm{C}$.

\section{Demineralization}

$\mathrm{HCl} 1 \mathrm{~N}$ solution is mixed with the fish scale of deproteinized, then heated for 1 hour at $65^{\circ} \mathrm{C}$. The mixture is stirred using a magnetic stirrer and cooled at room temperature. The mixture is filtered while rinsed using distilled water, then dried into the oven for 24 hours at $65^{\circ} \mathrm{C}$.

\section{Deacetylation}

Chitin which was obtained in the previous stage is immersed in a $50 \% \mathrm{NaOH}$ solution while heated at $100^{\circ} \mathrm{C}$ for 4 hours. The mixture is stirred using a magnetic stirrer and then cooled to room temperature. After that, washed using distilled water and immediately oven for 24 hours at $65{ }^{\circ} \mathrm{C}$ and the results obtained were weighed using an analytical balance, producing chitosan around $75 \%$ yield.

\section{Preparation of Composite of Hydrotalcite (Mg/Al) into Chitosan by Co-Precipitation Process}

$\mathrm{Mg}-\mathrm{Al}\left(\mathrm{NO}_{3}\right)$ with a ratio of 2 molar $\mathrm{Mg}^{2+} / \mathrm{Al}^{3+}$ is synthesized using the coprecipitation method. $70 \mathrm{~mL}$ solution containing $0.01 \mathrm{~mol}$ of $\mathrm{Mg}\left(\mathrm{NO}_{3}\right)_{2} .6 \mathrm{H}_{2} \mathrm{O}$ and $0.05 \mathrm{~mol}$ of $\mathrm{Al}\left(\mathrm{NO}_{3}\right)_{3} .9 \mathrm{H}_{2} \mathrm{O}$ is added drop by drop into $0.1 \mathrm{M} \mathrm{NaOH}$ and $2 \mathrm{M} \mathrm{Na}_{2} \mathrm{CO}_{3}$ solution until a solution of $1000 \mathrm{~mL}$ is obtained. The 
mixture is heated at $45^{\circ} \mathrm{C}$ with a mixing speed of $200 \mathrm{rpm}$.

One gram of chitosan is added to the mixture which is then dissolved in acetic acid by $2 \%(\mathrm{~b} / \mathrm{v})$, and dissolved in hydrotalcite $(\mathrm{Mg} / \mathrm{Al})$ while heating for 2 hours at $85^{\circ} \mathrm{C}$. The mixture is decanted for 12 hours and separated the top solution and bottom solution by pipette using a volume pipette. Then washed using distilled water until clean and dried using an oven at $60^{\circ} \mathrm{C}$ for 24 hours, later it is grounded into powder.

\section{Treatment Process of Raw Water PDAM Bandarmasih using Composite Mineral Hydrotalcite (Mg/Al) and Chitosan as Adsorbent}

Three beaker glass with a size of $1000 \mathrm{~mL}$ filled with raw water from PDAM Bandarmasih, then adding hydrotalcite chitosan for 1, 2 and 3 grams for each beaker glass. The mixture is then stirred at a speed of $200 \mathrm{rpm}$ for 1 hour. The recycle usage of such adsorbent was repeated for three times in triplicate analysis.

\section{RESULTS AND DISCUSSION}

Indonesia is famous for its maritime country because the sea area is more than the plain, so it is rich in marine products, especially fish, for example in Banjarmasin which is famous for 1000 rivers and wetlands where wetlands are used to cultivate fish primarily local fish (Haruan and Papuyu). The need for fish is increasing every year which results in problems especially fish scales which are disposed of uselessly.

Journal of Wetlands Environmental Management

Vol 7, No 1 (2019), 76 - 83

http://dx.doi.org/10.20527/jwem.v7.v1.197
Fish scales are still not widely used in Indonesia where only $20 \%$ is used to mixed animal feed ingredients and the rest even cause problems. This study aims to reduce the problem where these untapped fish scales can be used as chitosan which has many benefits, for example as natural preservatives, environmentally friendly bioplastics, natural ingredients in combination with other compounds and wastewater treatment where the results of this research are obtained chitosan from scales of Haruan and Papuyu fish.

Chitosan obtained from the deacetylation process can be measured DD\% from the results using FTIR analysis as shown in Figure 1.

The FTIR results can be calculate DD\% by the formula proposed by (Domszy and Roberts, 1985) based on the Baxter Method.

$\mathrm{A}_{1649}=\log (\% \mathrm{~T}), \mathrm{A}_{3462}=\log (\% \mathrm{~T})$

$\mathrm{DD} \%=100-\left(\mathrm{A}_{1649} / \mathrm{A}_{3462} \times 100 / 1.33\right)$

where:

DD : degree of deacetylation.

$\mathrm{A}_{1649}$ : adsorbent at wave number $1649 \mathrm{~cm}^{-1}$ which shows carbonyl uptake of amide.

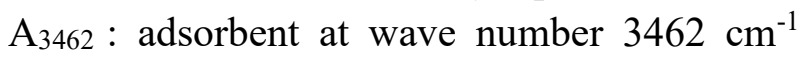
which is hydroxyl absorption.

DD is one of the chemical characteristics of $\mathrm{DD} \%$ calculation to find out this is chitosan or still chitin if DD is $75 \%$ or more, it can be said to be chitosan (Azhar et al. 2010). The DD\% obtained from the above calculation is $77.94 \%$ where chitosan obtained is combined again with hydrotalcite to increase the pores and extend the adsorbent surface so that the absorbency is faster. This can be proven by the SEM results obtained between chitosan and hydrotalcite(Mg/Al)/ chitosan (Figure 2). 


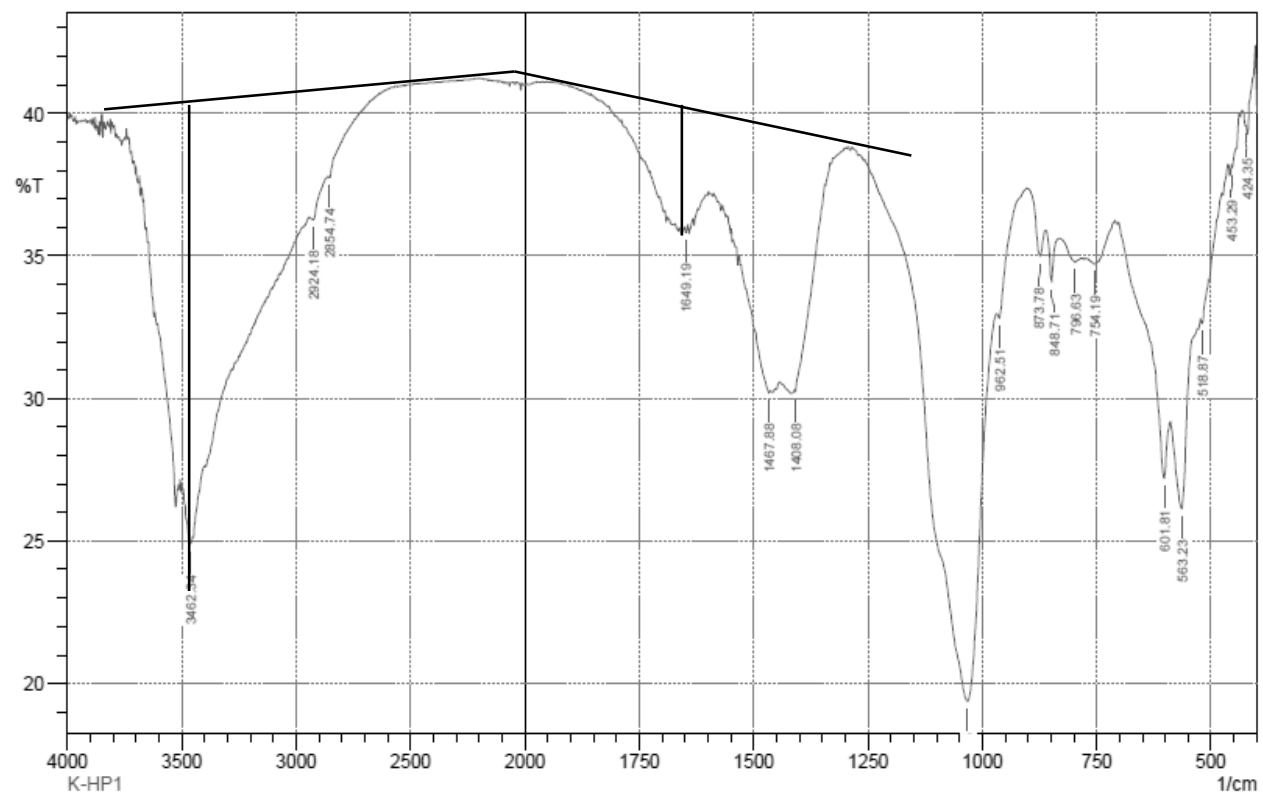

Figure 1. FTIR analysis of chitosan from Haruan and Papuyu fish scales
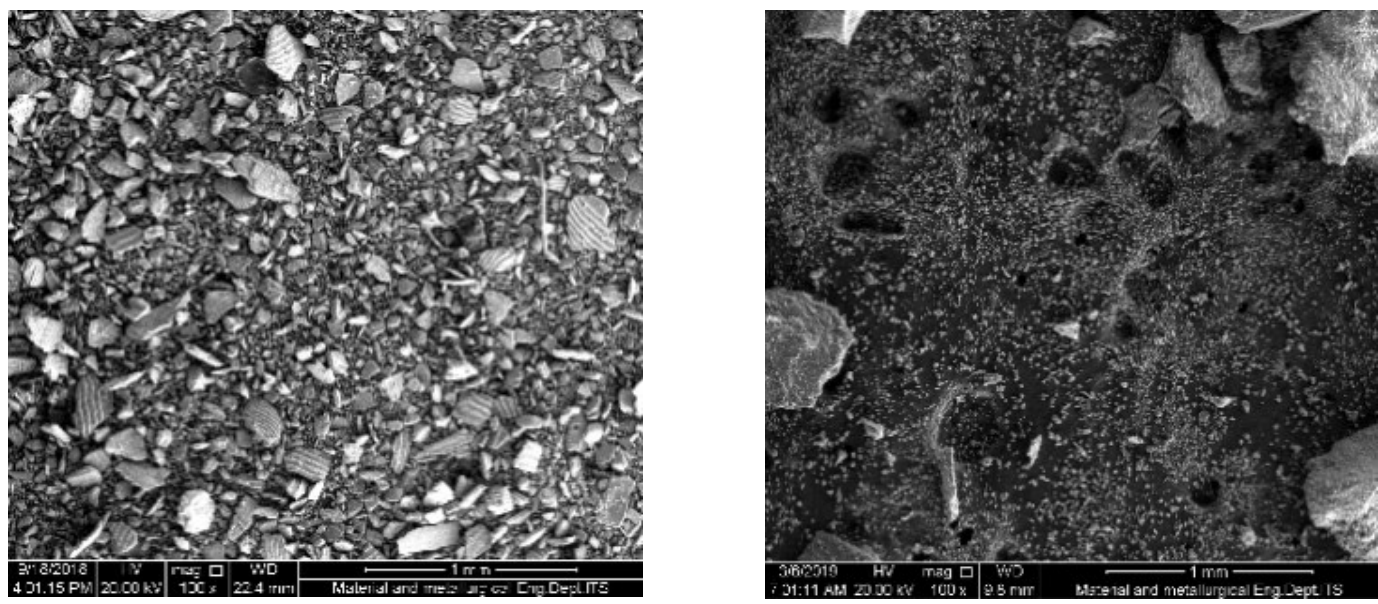

Figure 2. SEM morphology of (a) Chitosan (b) Hydrotalcite (Mg/A1)/Chitosan

The SEM results in figure 2 shown that the composite of hydrotalcite/chitosan pores are more than the chitosan pores itself and also the hydrotalcite+chitosan is smoother on the surface, so hydrotalcite+chitosan is better in the absorption process than chitosan.
Raw sources water samples taken from Bilu river, South Kalimantan at the dry season (AprilJune 2018). It is immediately placed in the storage cooler (below $4^{\circ} \mathrm{C}$ ) before use for the experiment. 
Preliminary data is obtained from the PDAM Banjarmasih itself where from the preliminary results Parameters that are not in accordance with drinking water according to the standards of regulation of the Minister of Health of the Republic of Indonesia No 492/MENKES/PER/IV/2010 and the results of analysis is found that color (Pt-Co) of 342, turbidity (NTU) of 37.55, and iron (Fe) 0.836 $\mathrm{mg} / \mathrm{L}$, while the requirements for drinking water are $15 \mathrm{PtCo}, 5 \mathrm{NTU}$, and $0.3 \mathrm{mg} / \mathrm{L}$, respectively. Therefore the parameters used are color, turbidity, and iron because it is not under drinking water requirements while according to the analysis data, another PDAM Bandarmasih is done accordingly. The handling of PDAM raw water is carried out by the adsorption method with hydrotalcite $(\mathrm{Mg} / \mathrm{Al}) /$ chitosan composite minerals which are varied by 1,2 and 3 grams/liter with a reaction time of 24 hours.

Table 1 shows changes the $\mathrm{pH}$ of the solution after and before the reaction with hydrotalcite (Mg/Al)/chitosan for 24 hours. The increase in $\mathrm{pH}$ after reacted with hydrotalcite adsorbent $(\mathrm{Mg} / \mathrm{Al}) /$ chitosan is likely due to hydrotalcite and chitosan itself in an alkaline atmosphere this was evidenced by research by
Imaniah (2016). The hydrotalcite $\mathrm{pH}$ is around 913 alkaline so it causes $\mathrm{pH}$ to rise according to the increase in the amount of hydrotalcite $(\mathrm{Mg} / \mathrm{Al}) /$ chitosan 1, 2 and 3 grams/liter with an increase in $\mathrm{pH}$ of 9.29, 9.88 and 10.21. It is still safe to drink often called alkaline water with a $\mathrm{pH}$ range of 8-11. Where the benefits of alkaline water if consumed continuously can hamper cancer growth (Catur, 2016).

The occurrence of a decrease in color after reacted with hydrotalcite adsorbent $(\mathrm{Mg} / \mathrm{Al}) /$ chitosan where the color undergoes negatively charged species dominate dissociation (Table 2). The color which causes more natural negatively charged species of dyes to interact with the surface of the hydrotalcite $(\mathrm{Mg} / \mathrm{Al})$ adsorbent and positively charged of chitosan. However, along with the increase in $\mathrm{pH}$ value, the higher the amount of the dye absorbed by hydrotalcite $(\mathrm{Mg} / \mathrm{Al}) /$ chitosan dose decreases because the effect of high $\mathrm{pH}$ is assumed to be positively hydrotalcite $(\mathrm{Mg} / \mathrm{Al})$ /chitosan where the real properties diminish. $\mathrm{pH}$ (Heraldy, 2017) Adsorption can be influenced by several parameters, namely $\mathrm{pH}$, reaction time, adsorbent dose and temperature (Zubair, 2017).

Table 1. Changes the $\mathrm{pH}$ of the solution after and before the reaction with hydrotalcite $(\mathrm{Mg} / \mathrm{Al}) /$ chitosan for 24 hours

\begin{tabular}{cccc}
\hline $\begin{array}{c}\text { Hydrotalcite } \\
(\mathrm{Mg} / \mathrm{Al}) / \text { chitosan }(\text { gram })\end{array}$ & $\begin{array}{c}\mathrm{pH} \text { before } \\
\text { reaction }\end{array}$ & $\begin{array}{c}\mathrm{pH} \text { after } \\
\text { reaction }\end{array}$ & $\begin{array}{c}\mathrm{pH} \text { percentage } \\
\text { change }(\%)\end{array}$ \\
\hline 1 gram & 7.49 & 8.29 & $11.00 \%$ \\
2 gram & 7.49 & 8.88 & $19.00 \%$ \\
3 gram & 7.49 & 9.21 & $23.00 \%$ \\
\hline
\end{tabular}

Journal of Wetlands Environmental Management

Vol 7, No 1 (2019), 76 - 83

http://dx.doi.org/10.20527/jwem.v7.v1.197 
Table 2. Changes in solution color after and before reacting with hydrotalcite (Mg/Al)/chitosan for 24 hours

\begin{tabular}{cccc}
\hline $\begin{array}{c}\text { Hydrotalcite } \\
(\mathrm{Mg} / \mathrm{Al}) / \text { Chitosan } \\
\text { (gram) }\end{array}$ & $\begin{array}{c}\text { Color before } \\
\text { reaction } \\
(\mathrm{PtCo})\end{array}$ & $\begin{array}{c}\text { Color after } \\
\text { reaction } \\
(\mathrm{PtCo})\end{array}$ & $\begin{array}{c}\text { Percentage } \\
\text { removal (\%) }\end{array}$ \\
\hline 1 gram & 342 & 11 & $96.78 \%$ \\
2 gram & 342 & 17 & $95.03 \%$ \\
3 gram & 342 & 24 & $92.98 \%$ \\
\hline
\end{tabular}

Table 3 shows changes in turbidity of the solution after and before reacting with hydrotalcite $(\mathrm{Mg} / \mathrm{Al})$ + chitosan for 24 hours. The occurrence of turbidity reduction after reacted with hydrotalcite adsorbent $(\mathrm{Mg} / \mathrm{Al}) /$ chitosan where turbidity is also called turbidity where turbidity is caused by suspense material such as particles of colloidal organic particles where hydrotalcite $(\mathrm{Mg} / \mathrm{Al}) /$ chitosan has excellent ability to separate particles of colloids with fine size can reduce the turbidity value (Imaniah, 2016).

Table 4 shows changes in iron $(\mathrm{Fe})$ solution after and before reacting with hydrotalcite
( $\mathrm{Mg} / \mathrm{Al}) /$ chitosan for 24 hours. The decrease in iron $(\mathrm{Fe})$ after reacted with hydrotalcite adsorbent $(\mathrm{Mg} / \mathrm{Al}) /$ chitosan where there is a decrease in iron in the solution due to hydrotalcite $(\mathrm{Mg} / \mathrm{Al}) /$ chitosan which is positively charged as a result of the persistent substitution of cations divalent by trivalent cations and has an empty interlayer area that is used to adsorb metal anions in this case iron in the solution that causes iron to dissolve after the reaction becomes a decrease where on the surface of hydrotalcite $(\mathrm{Mg} / \mathrm{Al}) /$ chitosan has an electrostatic force or attractive force between metal in solution.

Table 3. Changes in turbidity of the solution after and before reacting with hydrotalcite $(\mathrm{Mg} / \mathrm{Al}) /$ chitosan for 24 hours

\begin{tabular}{cccc}
\hline $\begin{array}{c}\text { Hydrotalcite }(\mathrm{Mg} / \mathrm{Al})+ \\
\text { chitosan (gram) }\end{array}$ & $\begin{array}{c}\text { Turbidity } \\
\text { before reaction } \\
\text { (NTU) }\end{array}$ & $\begin{array}{c}\text { Turbidity } \\
\text { after reaction } \\
\text { (NTU) }\end{array}$ & $\begin{array}{c}\text { Percentage } \\
\text { removal (\%) }\end{array}$ \\
\hline 1 gram & 37.55 & 0.76 & $97.98 \%$ \\
2 gram & 37.55 & 7.6 & $79.76 \%$ \\
3 gram & 37.55 & 8.8 & $76.56 \%$ \\
\hline
\end{tabular}

Table 4. Changes in iron (Fe) solution after and before reacting with hydrotalcite $(\mathrm{Mg} / \mathrm{Al}) / \mathrm{chitosan}$ for 24 hours

\begin{tabular}{cccc}
\hline $\begin{array}{c}\text { Hydrotalcite } \\
(\mathrm{Mg} / \mathrm{Al}) / \text { chitosan } \\
(\mathrm{gram})\end{array}$ & $\begin{array}{c}\text { Iron before } \\
\text { reaction }(\mathrm{mg} / \mathrm{L})\end{array}$ & $\begin{array}{c}\text { Iron after } \\
\text { reaction }(\mathrm{mg} / \mathrm{L})\end{array}$ & $\begin{array}{c}\text { Percentage } \\
\text { removal }(\%)\end{array}$ \\
\hline 1 gram & 0.836 & 0.047 & $94.38 \%$ \\
2 gram & 0.836 & 0.052 & $93.78 \%$ \\
3 gram & 0.836 & 0.068 & $91.87 \%$ \\
\hline
\end{tabular}

Journal of Wetlands Environmental Management

Vol 7, No 1 (2019), 76 - 83

http://dx.doi.org/10.20527/jwem.v7.v1.197 


\section{CONCLUSIONS}

The composite of hdrotalcite $(\mathrm{Mg} / \mathrm{Al}) /$ chitosan were successfully synthesized using co-precipitation process. Batch experimental experiment for treating raw water of municipal waterwork PDAM Bandarmasih using the composite adsorbent reduce significantly color, turbidity and iron metal in the solution. The decreasing in color due to the amount of hydrotalcite $(\mathrm{Mg} / \mathrm{Al}) /$ chitosan because color are dominated by species that are negatively charged so that it is easy to interact with the surface of the adsorbent which is positively charged and therefore occurs a tensile force which causes the dye in the solution to decrease.

Turbidity is dissolved because of the ability of hydrotalcite $(\mathrm{Mg} / \mathrm{Al})+$ chitosan itself which is suitable for separating colloidal particle with fine sizing size so that it can reduce turbidity value that we know turbidity is caused by suspense material such as particle organic and particles colloid. The removal of iron $(\mathrm{Fe})$ in the solution due to hydrotalcite $(\mathrm{Mg} / \mathrm{Al}) /$ chitosan which is positively charged as a result of the persistent substitution of cations divalent by trivalent cations and has an empty interlayer area which is used to adsorb metal anions in this case iron in the solution it causes iron to be dissolved after the reaction becomes a decrease where on the surface of hydrotalcite $(\mathrm{Mg} / \mathrm{Al})$ /chitosan has an electrostatic force or attractive force between metals in the solution which results in a reduction.

The optimum dose of adsorbent hydrotalcite $(\mathrm{Mg} / \mathrm{Al}) /$ chitosan to treating the raw water of PDAM Bandarmasih is around $1 \mathrm{~g} / \mathrm{L}$ where the higher the $\mathrm{pH}$ the less favorable the result according to the Regulations Minister of Health of the Republic of Indonesia no: 492/MENKES/PES/IV/2010.

\section{ACKNOWLEDGMENT}

This work was financially supported by a grant of Directorate of Research and Community Service, The Ministry of Research, Technology and Higher Education of Indonesia (Project No: 040/UN8.2/PL/2018), the fund for Applied Research University Grant.

\section{REFERENCES}

Azhar, M. Efendi J., Syofyeni E., Lesi R. M., and Novalina S. (2010). Pengaruh Konsentrasi $\mathrm{NaOH}$ dan $\mathrm{KOH}$ terhadap Derajat Deasetilasi Kitin dari Limbah Kulit Udang, Eksakta, 1(XI), pp. 1-8.

Badan Pusat Statistik. 2015. Jumlah Penduduk Kota Banjarmasin Menurut Jenis Kelamin, Badan Pusat Statistik Banjarmasin. (online), (http://banjarmasinkota.bps.go.id, html diakses 20 Desember 2018)

Catur, M Marliando Satria Pangestu, Sukohar, A. (2016). Air Alkali Terionisasi Pencegahan Termutakhir Timbulnya Kanker Ionized Alkaline Water as the Latest Prevention of Cancer Emergence', Majority, 5(April), pp. 74-80.

Domszy, J. G., Roberts, G. A. F. (1985) Evaluation of infrared spectroscopic techniques for analysing chitosan, Die Makromolekulare Chemie, 186 (8), 16711677.

Journal of Wetlands Environmental Management

Vol 7, No 1 (2019), 76 - 83

http://dx.doi.org/10.20527/jwem.v7.v1.197 
Heraldy, E., Khoirina Dwi, N. and Heriyanto, H (2017). Kalsinasi Ca-Mg-Al Hydrotalcite dari Brine Water dan Karakterisasinya, ALCHEMY Jurnal Penelitian Kimia, 13(2), pp. 205-216. doi: 10.20961/alchemy.v13i2.5606.

Imaniah, N. (2016). Preparasi Komposit Mg/AlNO3 Hidrotalsit-Magnetit Kalsinasi Dengan Metode Kopresipitasi Dan Aplikasinya Untuk Adsorben Zat Warna Remazol Yellow FG. Skripsi. Universitas Negeri Semarang.

Ministry of Marine Affairs and Fisheries. 2014. Tentang Jaring Bertumbuhan, Berkembang, dan Berdaya Saing Perekonomian Kelautan. Jakarta: Kementerian Kelautan Dan Perikanan Indonesia.
Minister of Health of the Republic of Indonesia. 2010. Persyaratan Kualitan Air Minum. Jakarta: Kementerian Kesehatan Republik Indonesia.

No, H. K., Meyers, S. P. (1995) Preparation and Characterization of Chitin and Chitosan-A Review, Journal of Aquatic Food Product Technology, 4 (2), 27-52.

Zubair. M., Daud, M., McKay, G., Shehzad F., and Al-Harthi, M.A. (2017). Recent progress in layered double hydroxides (LDH)-containing hybrids as adsorbents for water remediation, Applied Clay Science, 143, pp. 279-292.

Journal of Wetlands Environmental Management

Vol 7, No 1 (2019), 76 - 83

http://dx.doi.org/10.20527/jwem.v7.v1.197 